\title{
RESISTANCE IMPROVEMENT OF RUBBERWOOD TREATED WITH ZINC OXIDE NANOPARTICLES AND PHENOLIC RESIN AGAINST WHITE-ROT FUNGI, Pycnoporus sanguineus
}

\author{
Mohd Khairun Anwar Uyup ${ }^{1, \star}$, Tumirah Khadiran ${ }^{1}$, Hamdan Husain $^{1}$, Sabiha Salim$^{2}$, \\ Nordahlia Abdullah Siam ${ }^{1}$, Lee Seng Hua ${ }^{3}$
}

\begin{abstract}
Phenolic resin or phenol formaldehyde (PF) resin containing different percentage of zinc oxide $(\mathrm{ZnO})$ nanoparticles was prepared and used to treat rubberwood. Three types of treatment solutions were prepared, namely (1) low molecular weight phenol formaldehyde resin (LMwPF), (2) 1,5 wt \% nano ZnO dissolved in water $\left(\mathrm{ZnO} / \mathrm{H}_{2} \mathrm{O}\right)$, and (3) combination of both $\mathrm{LMwPF}$ and $1,5 \mathrm{wt} \%$ nano $\mathrm{ZnO}(\mathrm{LMwPF} / \mathrm{ZnO})$. The rubberwood samples were submerged into the treatment solutions for 60,90 , and $120 \mathrm{~min}$, before vacuum impregnation. The untreated rubberwood samples served as the controlled samples. The thermal stability behaviour and resistance against white-rot fungi (Pycnoporus sanguineus) of the treated rubberwood samples were evaluated. The results reveal that the treated rubberwood had slightly better thermal stability compared to the untreated samples. In terms of decay resistance, the rubberwood treated with LMwPF and LMwPF/ZnO possess very high resistance against white-rot fungi. On the other hand, the rubberwood treated with $\mathrm{ZnO} / \mathrm{H}_{2} \mathrm{O}$ did not attain similar effectiveness as the other two treatments, except for the samples that were submerged in $\mathrm{ZnO} / \mathrm{H}_{2} \mathrm{O}$ for $120 \mathrm{~min}$. The results indicate that $1,5 \mathrm{wt} \%$ nano $\mathrm{ZnO}$ could be sufficient in imparting superior durability to rubberwood provided that longer submersion time is adopted.
\end{abstract}

Keywords: Fungal resistance, Hevea brasilensis, impregnation modification, phenol formaldehyde, resin, thermal stability.

\section{INTRODUCTION}

Rubberwood (Hevea brasiliensis) is a very important plantation crop in Southeast Asian countries, particularly Malaysia. However, it is a non-durable wood which is very prone to the attack by fungi and insects that starts almost immediately after the tree is felled. Blue stain fungi, ambrosia beetles, and powder-post beetles are among the fungi and insects that invade rubberwood and render it non-usable (Browne 1961, Hong et al. 1980, Norhara 1981). Owing to this, rubberwood is mainly used interiorly such as furniture where its light colour and good appearance are certainly adding value to the designated application (Ratnasingam et al. 2011). In order to enhance the biological durability of rubberwood, preservative treatment must be carried out. Fortunately, rubberwood is very amenable to preservatives and very easy to be treated. Application of conventional wood preservative such as chromated copper arsenate (CCA) and boron is a common practice in treating rubberwood (Yang et al. 2006). However, both preservatives impose adverse effects to the environment and has fixation problem in wood. Hence, alternative preservative like copper chromate borate (CCB) is a potential candidate (Gallio et al. 2018). Apart from that, various green preservation techniques have been proposed. For

\footnotetext{
${ }^{1}$ Forest Products Division, Forest Research Institute Malaysia, 52109 Kepong, Selangor,Malaysia.

${ }^{2}$ Faculty of Forestry, Universiti Putra Malaysia, 43400 UPM Serdang, Selangor, Malaysia.

${ }^{3}$ Institute of Tropical Forestry and Forest Products, Universiti Putra Malaysia, 43400 UPM Serdang, Selangor, Malaysia.

"Corresponging author: mkanwar@frim.gov.my

Received: 31.10.2018 Accepted: 26.05.2019
} 
instance, plant essential oils such as lavender oil, lemon grass oil, and thyme oil were found very effective in protecting the wood from fungi attack (Bahmani and Schmidt 2018). Heat treatment with the application of vegetables oil as heating medium is also a promising method to enhance the biological durability of wood (Lee et al. 2018).

In order to enhance wood durability against biodeterioration agents, one of the promising techniques is to impregnate the wood with either nano-sized zinc oxide $(\mathrm{ZnO})$ or zinc borate, which allow the penetrants to penetrate the cell wall to a greater extent. $\mathrm{ZnO}$ nanoparticles have wide applications in various areas including pharmaceutical for the manufacturing of sunscreens products (Jeon et al. 2016, Dao et al. 2016, Zuzanna et al. 2013), wastewater treatment (Wang et al. 2008), and as an antifungal and antibacterial agent (Sawai, 2003, Sawai and Yoshikawa 2004, Jain et al. 2009). ZnO nanoparticles are known to have good antimicrobial ability (Iždinský et al. 2018). Lykidis et al. (2016) impregnated Scots pine with nano $\mathrm{ZnO}$ and zinc borate using the full cell process and significantly improved the resistance of the impregnated wood against brown rot fungi, Serpula lacrymans. In a study by Ghorbani-Kookandeh et al. (2014), beech wood impregnated with $\mathrm{ZnO}$ nanoparticles exhibited significant improvement in resistance against white-rot fungi, Trametes versicolor. Besides, paper made with $\mathrm{ZnO}$ nanoparticles-treated pulp fibres possessed superior antimicrobial effect against Escherichia coli and Staphylococcus aureus, a Gram-negative and Gram-positive bacterium, respectively. Apart from fungi and bacteria, the impregnation of nano $\mathrm{ZnO}$ also bestow the wood with better resistance against Subterranean termites (Akhtari and Nicholas 2013).

Phenolic resin is one of the well-known wood surface protectors which is widely used in wood-based industry, due to its high flexibility, excellent water resistance, good mechanical properties, good resistance to acids, low cost, and simple production process. It is also non-toxic and difficult to ignite (Furuno et al. 2004, Dong et al. 2009, Huang et al. 2014). Altering the phenolic resin properties using ZnO nanoparticles as additive should improve the level of wood protection especially against decay fungi and UVA radiation. $\mathrm{ZnO}$ nanoparticle is an inorganic material which has a wide band gap $(3,37 \mathrm{eV})$ and large excitation binding energy of $60 \mathrm{meV}$. Therefore, it can absorb light that matches or exceeds their band gap energy, which lies in the UV range of the solar spectrum; thus it can function as a UV absorber (Fangli et al. 2003). Aiming to improve the biological resistance of the wooden composites, Gao et al. (2018) modified the aqueous phenol formaldehyde (PF) resin using nano copper oxide $(\mathrm{CuO})$. The PF resin, along with superior biological resistance ability, displayed self-curing properties that can compensate the adverse effects on mechanical strength. However, few studies have been performed to assess the effect of $\mathrm{ZnO}$ nanoparticles as anti-wood decaying fungi (mold, sapstain, white- and brown-rot) (Mantanis et al. 2014).

Therefore, this study aims to evaluate the effect of $\mathrm{ZnO}$ nanoparticles in low molecular weight phenol formaldehyde (LMwPF) resin on the durability of rubberwood towards white-rot fungi under laboratory conditions. To achieve the objective of this study, different concentrations of $\mathrm{ZnO}$ nanoparticle were incorporated into the LMwPF resin formulation for impregnation treatment. The interaction between $\mathrm{ZnO}$ nanoparticle with LMwPF resin, the effect of curing time, and several properties were investigated by Fourier transform infrared spectroscopy (FTIR) and thermo gravimetric analysis (TGA/DTG). The thermal behaviour of ZnO nanoparticles loaded LMwPF resin impregnated into the rubberwood was also characterised using TGA/DTG. The morphology and dispersibility properties of $\mathrm{ZnO} / \mathrm{PF}$ solution into the rubberwood structure were characterised using SEM.

\section{MATERIALS AND METHODS}

\section{Preparation of materials}

Kiln dried rubberwood (Hevea brasilensis) was obtained from a commercial market in Selangor. The rubberwood was cut into the dimension of $25 \times 25 \times 9 \mathrm{~mm}$ before they were conditioned to an equilibrium moisture content of $20 \%$ in a conditioning room. Novalac type low molecular weight phenol formaldehyde (LMwPF) was purchased from a local manufacturer located in Shah Alam, Selangor. The LMwPF (Mw 600) with $45 \%$ solid content was used. Nano $\mathrm{ZnO}$ modified with octadecyl ammonium/silane used in this study was obtained from Nanocor Inc. 


\section{Impregnation treatment}

The rubberwood samples were treated with three types of treatment preservatives, namely (1) $45 \%$ low molecular weight phenol formaldehyde resin (LMwPF), (2) $1,5 \mathrm{wt} \%$ nano zinc oxide dissolved in water $(\mathrm{ZnO} /$ $\mathrm{H}_{2} \mathrm{O}$ ), and (3) combination of 45\% LMwPF and 1,5 wt \% nano zinc oxide (LMwPF/ZnO). The solutions were mixed for $40 \mathrm{~min}$. A set of untreated samples was prepared to serve as the controlled samples. All treatments were conducted at Forest Research Institute Malaysia (FRIM) in Kepong. Prior to vacuum impregnation, the rubberwood samples were submerged in the preservatives for 60, 90, and $120 \mathrm{~min}$. Eight replications were prepared for each treatment. After that, the samples were vacuum impregnated for $1 \mathrm{hr}$ and then, the pressure was slowly released for 90 min from the vacuum chamber. The samples were then taken out and dried in an oven at $60{ }^{\circ} \mathrm{C}$ for $48 \mathrm{hr}$. The weight percent gain (WPG) of the samples after impregnation were determined.

\section{Fourier transform infrared spectroscopy (FTIR) analysis}

FTIR was used to characterise the chemical changes in LMwPF due to the addition of $\mathrm{ZnO}$ nanoparticle before impregnating into wood. The chemical changes of the cured LMwPF resin and LMwPF/ZnO (cured at $103{ }^{\circ} \mathrm{C}$ for $6 \mathrm{~h}$ in an oven) were measured in the range of wavelengths between 280 and $4000 \mathrm{~cm}^{-1}$ using a Perkin Elmer FTIR instrument $\left(1 \mathrm{~cm}^{-1}\right.$ resolution, 32 scans, $\mathrm{KBr}$ method). The analysis was carried out at room temperature.

\section{Thermal stability}

Thermal stability properties of the rubberwood treated with $\mathrm{LMwPF} / \mathrm{ZnO}$ nanoparticles were analysed using a thermal gravimetric analysis (TGA/DTG), SDT Q 600 research instrument at a heating rate of $10^{\circ} \mathrm{C} / \mathrm{min}$, from 25 to $1000{ }^{\circ} \mathrm{C}$ under nitrogen atmosphere. Mass of the sample used was around 10-15 mg. Derivative thermal gravimetric (DTG) was also obtained to determine the maximum rate of weight loss.

\section{Surface morphology}

Morphology and microstructure of rubberwood treated with $\mathrm{LMwPF} / \mathrm{ZnO}$ were observed by SEM, JEOL variable pressure SEM (VP-SEM 1455). A small wood block of $10 \times 10 \times 12 \mathrm{~mm}$ was prepared from the treated rubberwood samples. Then, the centre of the treated wood block was sliced from the transverse section using a microtome to obtain a 5-mm thick specimen. The dried sliced samples were put on a conductive carbon adhesive tape surface which was attached to the SEM stub, and then Pd/gold coated on the cutting surface and viewed at an accelerated voltage of $20 \mathrm{kV}$.

\section{Fungus test}

Both treated and untreated rubberwood samples were tested for durability according to the procedures specified in ASTM 2017 - 05 (Standard Test Method of Natural Decay Resistance of Wood). White-rot fungus, Pycnoporus sanguineus was used as the test fungus. The feeder strip from rubberwood with dimension of 3 $\times 29 \times 35 \mathrm{~mm}$ were prepared and conditioned. Malt extract agar (MEA) was used as a nutrient medium for culturing the fungus. An amount of $2 \mathrm{wt} \%$ malt extract and $1,5 \mathrm{wt} \%$ weight agar was prepared by mixing it with distilled water in a bottle. The medium was sterilised at $121^{\circ} \mathrm{C}$ for $20 \mathrm{~min}$ and allowed to cool before inoculations. After the medium was cooled and solidified, the white-rot fungus was inoculated on the surface of the media and incubated in an incubator at $27+2{ }^{\circ} \mathrm{C}$ for about $4-5$ days until the mycelium covered at leasttwo-third of the petri dish. Then, a sterile test block was placed on the feeder strips and transferred into the culture bottle. Prior to the transferring test block and feeder strip into the culture bottle, $150 \mathrm{~g}$ sieved soil and $70 \mathrm{ml}$ distilled water was added into the culture bottle. After the test blocks were introduced into the culture bottles, they were left to incubate for 16 weeks. At the end of the test, the test blocks were cleaned for removing all the mycelium on the surfaces. The test blocks were then oven-dried until the constant weights were reached and the percentage of weight loss caused by white-rot fungus was determined.

\section{RESULTS AND DISCUSSION}

\section{Chemical property of LMwPF/ZnO}

Figure 1 shows the FTIR spectra of pure LMwPF and LMwPF/ZnO nanocomposite prepared using different concentration of $\mathrm{ZnO}$ nanoparticles. Band at $3461 \mathrm{~cm}^{-1}$ corresponds to the $-\mathrm{OH}$ functional group, while 
bands at 2920 and $2851 \mathrm{~cm}^{-1}$ corresponds to $-\mathrm{CH}$ stretching. Bands at $1220 \mathrm{~cm}^{-1}$ are assigned to $\mathrm{C}-\mathrm{O}$ stretching vibrations of phenolic resin. The band at $3461 \mathrm{~cm}^{-1}$ for $\mathrm{LMwPF} / \mathrm{ZnO}$ nanocomposite sample shows a decrease in intensity compared to that of the pure LMwPF resin, suggesting that the -OH functional groups of phenolic resin were occupied by the $\mathrm{ZnO}$ nanoparticles. The similar observation was reported by Dhoke et al. (2009) when using $\mathrm{ZnO}$ nanoparticle in the alkyd-based waterborne coating formulation. The other absorption peaks of phenolic resin containing $0 ; 0,5 ; 1 ; 1,5 ; 2$, and $2,5 \mathrm{wt} \% \mathrm{ZnO}$ did not change significantly, indicating that the structure of the LMwPF resin was unaltered by the addition of $\mathrm{ZnO}$ nanoparticles. However, LMwPF/ $\mathrm{ZnO}$ nanocomposite mixture prepared using $1,5 \mathrm{wt} \% \mathrm{ZnO}$ nanoparticles was chosen for further study.

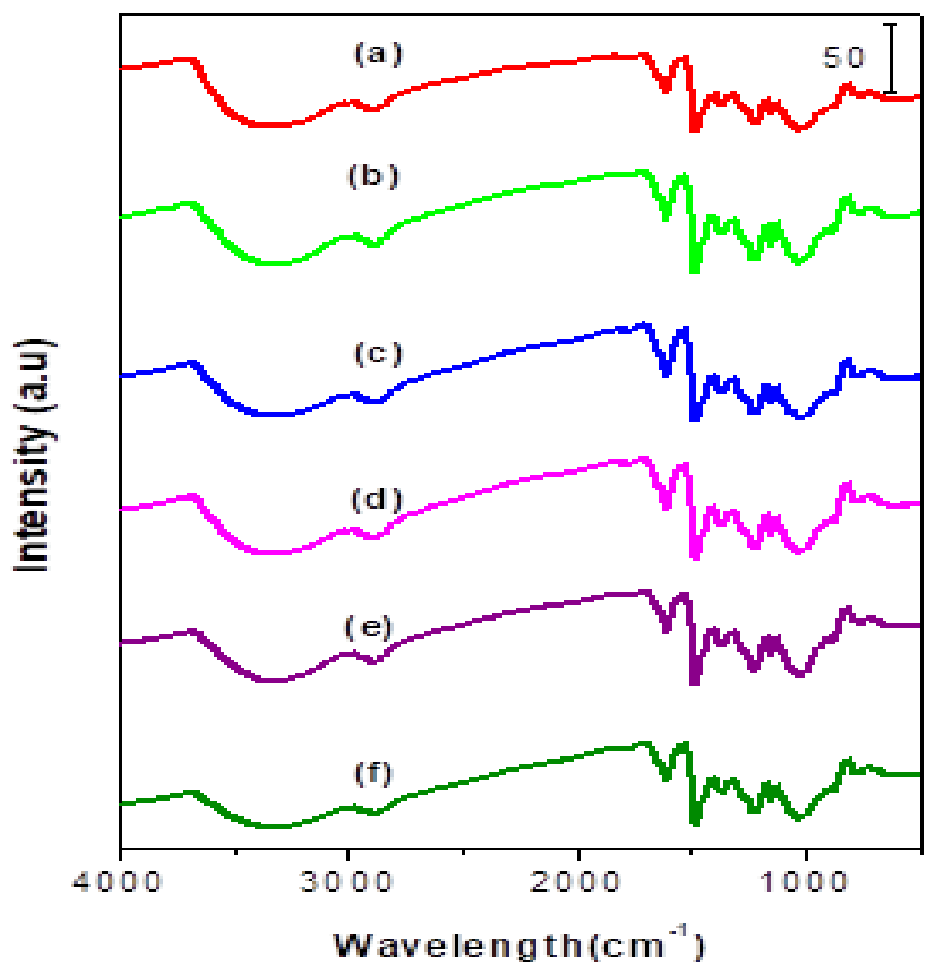

Figure 1: FTIR spectra of (a) pure LMwPF resin, LMwPF containing (b) $0,5 \mathrm{wt} \%$, (c) 1,0 wt \%, (d) $1,5 \mathrm{wt}$ $\%$, (e) $2,0 \mathrm{wt} \%$, and $2,5 \mathrm{wt} \%$ of $\mathrm{ZnO}$ nanoparticles.

\section{Weight percent gain (WPG)}

The WPG of the rubberwood treated with different types of solution are shown in Table 1. The WPG is a function of submersion time where the longer the submersion time, the higher the WPG of the samples. The rubberwood treated with $\mathrm{ZnO} / \mathrm{H}_{2} \mathrm{O}$ recorded the lowest WPG ranging from 1,07\% to 1,54\%. Meanwhile, the rubberwood treated with $\mathrm{LMwPF} / \mathrm{ZnO}$ has the highest WPG $(6,30 \%-7,13 \%)$ compared to that of the samples treated with LMwPF solely (4,19\%-4,52\%). According to Dungani et al. (2014), PF resin could only penetrate the wood cell lumen and has high tendency of leaching out from the lumen. On the other hand, addition of nanoparticles could assist the fixation and polymerisation of PF resin after impregnation and subsequently resulted in higher WPG compared to the wood impregnated with PF resin solely. 
Table 1: The WPG of the rubberwood samples treated with different types of solution.

\begin{tabular}{|c|c|c|}
\hline Type of treatment & Submersion time (min) & $\begin{array}{c}\text { Weight percent gain } \\
(\mathbf{\%})\end{array}$ \\
\hline Untreated & 0 & - \\
\hline LMwPF & 60 & 4,19 \\
\hline & 90 & 4,37 \\
\hline & 120 & 4,52 \\
\hline $\mathrm{LMwPF} / \mathrm{ZnO}$ & 60 & 6,30 \\
\hline & 90 & 6,87 \\
\hline & 120 & 7,13 \\
\hline $\mathrm{ZnO} / \mathrm{H}_{2} \mathrm{O}$ & 60 & 1,16 \\
\hline & 90 & 1,07 \\
\hline & 120 & 1,54 \\
\hline
\end{tabular}

\section{Thermal behavior}

The TGA/DTG thermograms of $\mathrm{ZnO}$ nanoparticles, pure LMwPF resin, LMwPF/ZnO nanocomposite treated and untreated rubberwood are presented in Figure 2. Table 2 shows the TGA/DTG data of ZnO nanoparticles, pure LMwPF, $\mathrm{LMwPF} / \mathrm{ZnO}$ treated and untreated rubberwood. TGA/DTG thermograms for all specimens clearly show that the mass loss was implemented in two steps. The first mass loss was performed at temperatures between room temperature and $120^{\circ} \mathrm{C}$ due to the evaporation of water. The water loss for each specimen occurred at below $100^{\circ} \mathrm{C}$. The DTG of rubberwood treated with nano $\mathrm{ZnO}$ has a high quantity of water than those of the untreated rubberwood, rubberwood treated with LMwPF resin, and rubberwood treated with $\mathrm{LMwPF} / \mathrm{ZnO}$. High water content in the rubberwood treated with nano $\mathrm{ZnO}$ is due to the existence of water used as $\mathrm{ZnO}$ carrier during treatment process.

Figure 2 also shows that the specimen exhibited further degradation steps at the range from 150 to 470 ${ }^{\circ} \mathrm{C}$. The degradation phenomena of the specimens are generally attributed to the degradation of cellulose and lignin of the rubberwood. However, the degradation reactions of the samples here were different in terms of their energies of activation, depending on the type of treatment used. Based on DTG, the degradation of the untreated rubberwood was higher $(68,5 \%)$, followed by $\mathrm{ZnO}$-treated rubberwood (67,5\%), LMwPF-treated rubberwood (67,5\%), and $\mathrm{LMwPF} / \mathrm{ZnO}$ - treated rubberwood $(66,6 \%)$. This means that $\mathrm{LMwPF} / \mathrm{ZnO}$ polymer slightly improved the thermal stability of rubberwood. This phenomenon could possibly attribute to the higher WPG resulted by the LMwPF/ZnO solution as a higher amount of materials has been impregnated into the rubberwood and led to a more thermally stable structure (Dungani et al. 2014).

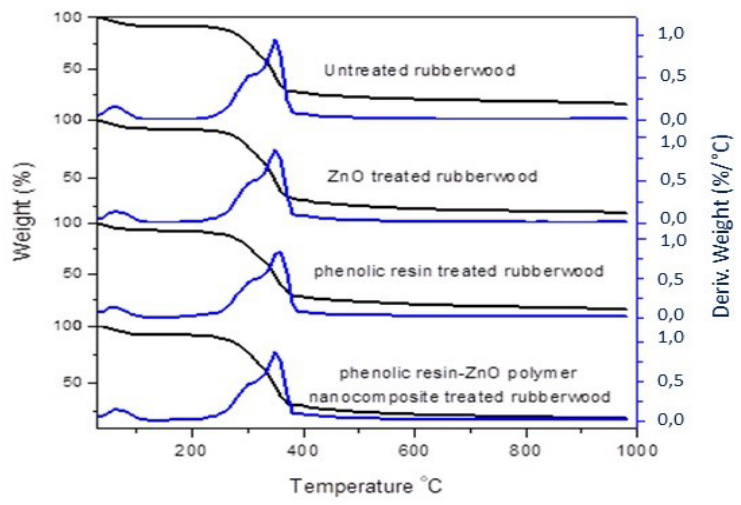

Figure 2: TGA/DTG thermograms of $\mathrm{ZnO}$ nanoparticles, pure LMwPF resin and LMwPF/ZnO-treated rubberwood. 
Table 2: TGA/DTG data of $\mathrm{ZnO}$ nanoparticles, pure $\mathrm{LMwPF}$ resin and $\mathrm{LMwPF} / \mathrm{ZnO}$-treated rubberwood.

\begin{tabular}{|c|c|c|c|c|c|c|}
\hline Samples & $\begin{array}{c}\text { TGA } \\
\text { degradation } \\
\text { of interval } \\
\left.\text { step 1 } \mathbf{(}^{\mathbf{0}} \mathbf{C}\right)\end{array}$ & $\begin{array}{c}\text { DTG } \\
\text { peak of } \\
\text { step 1 } \\
\left.\mathbf{(}^{\mathbf{O}} \mathbf{C}\right)\end{array}$ & $\begin{array}{c}\text { Percent } \\
\text { mass } \\
\text { loss } \\
\mathbf{( \% )}\end{array}$ & $\begin{array}{c}\text { TGA } \\
\text { degradation } \\
\text { of interval } \\
\left.\text { step 2 } \mathbf{(}^{\mathbf{0}} \mathbf{C}\right)\end{array}$ & $\begin{array}{c}\text { DTG } \\
\text { peak of } \\
\text { step 2 } \\
\mathbf{(} \mathbf{C})\end{array}$ & $\begin{array}{c}\text { Percent } \\
\text { mass } \\
\text { loss } \\
\mathbf{( \% )}\end{array}$ \\
\hline Untreated & $30-120$ & 60,3 & 3,9 & $150-470$ & 352 & 68,5 \\
\hline ZnO-treated & $30-120$ & 60,3 & 3,9 & $150-470$ & 352 & 67,5 \\
\hline LMwPF-treated & $30-120$ & 56,9 & 3,3 & $150-470$ & 352 & 67,5 \\
\hline $\begin{array}{c}\text { LMwPF/ZnO- } \\
\text { treated }\end{array}$ & $30-120$ & 62,8 & 3,5 & $150-470$ & 352 & 66,6 \\
\hline
\end{tabular}

\section{Morphology of treated rubberwood}

SEM was used to characterise the surface morphology of rubberwood treated with $\mathrm{LMwPF} / \mathrm{ZnO}$ solution. The SEM image of the treated rubberwood is presented in Figure 3. The experiments were carried out to study the dispersibility of nano $\mathrm{ZnO}$ and LMwPF resin in wood cells structure. As shown in Figure 3, the $\mathrm{ZnO}$ nanoparticles (white) and LMwPF resin (black) were well dispersed in the wood cells structure. From Figure 3 , the LMwPF/ZnO admixture has deposited on the cell wall and cell lumen, indicating good penetration of the solution.

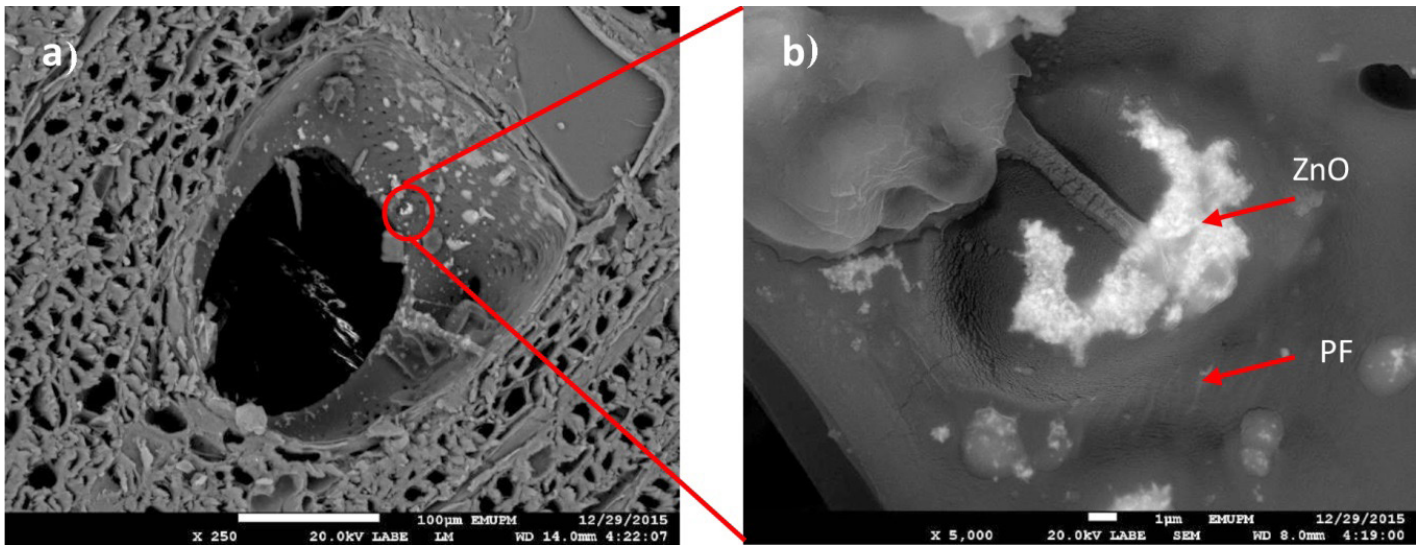

Figure 3: SEM images of LMwPF/ZnO-treated rubberwood: a) magnificent $250 \times$ and b) magnificent 5000×.

\section{Fungus test}

Table 3 summarises the percentage of weight loss and resistance class of the treated and untreated rubberwood after 8-weeks exposure to the white-rot fungus. The resistance classes were classified based on the weight loss of samples according to American Society for Testing and Materials (ASTM) ASTM D2017. According to the standard, the untreated rubberwood with $26,7 \%$ weight loss falls into the class of moderate resistance (Class 3 ) towards $P$. sanguineus. For the samples treated with nano zinc oxide dissolved in water $\left(\mathrm{ZnO} / \mathrm{H}_{2} \mathrm{O}\right)$, significant improvement in fungus resistance was observed and the improvement increased with increasing submerging times. Samples that were submerged in $\mathrm{ZnO} / \mathrm{H}_{2} \mathrm{O}$ for $60 \mathrm{~min}$ before the vacuum impregnation treatment fall into Class 2 of resistance, with a weight loss of $15,0 \%$ after exposure to the fungus. On the other hand, the weight loss of the samples submerged in $\mathrm{ZnO} / \mathrm{H}_{2} \mathrm{O}$ for 90 and $120 \mathrm{~min}$ before the vacuum impregnation treatment were $9,9 \%$ and $1,6 \%$, respectively, which is highly resistance (Class 1 ) towards Pycnoporus sanguineus. 
Table 3: Percentage of weight loss and resistance class of the treated and untreated rubberwood after 8-weeks exposure to Pycnoporus sanguineus.

\begin{tabular}{|c|c|c|c|}
\hline $\begin{array}{c}\text { Type of } \\
\text { treatment }\end{array}$ & Submersion time (min) & Mass loss (\%) & $\begin{array}{c}\text { Resistance } \\
\text { Class }\end{array}$ \\
\hline Untreated & 0 & $26,7 \pm 3,5^{\mathrm{d}}$ & 3 \\
\hline $\mathrm{LMwPF}$ & 60 & $0,29 \pm 0,12^{\mathrm{a}}$ & 1 \\
\hline & 90 & $0,25 \pm 0,10^{\mathrm{a}}$ & 1 \\
\hline & 120 & $0,15 \pm 0,10^{\mathrm{a}}$ & 1 \\
\hline $\mathrm{LMwPF} / \mathrm{ZnO}$ & 60 & $0,26 \pm 0,20^{\mathrm{a}}$ & 1 \\
\hline & 90 & $0,21 \pm 0,17^{\mathrm{a}}$ & 1 \\
\hline & 120 & $0,10 \pm 0,12^{\mathrm{a}}$ & 1 \\
\hline $\mathrm{ZnO} / \mathrm{H}_{2} \mathrm{O}$ & 60 & $15,0 \pm 2,9^{\mathrm{c}}$ & 2 \\
\hline & 90 & $9,9 \pm 10,5^{\mathrm{bc}}$ & 1 \\
\hline & 120 & $1,6 \pm 0,5^{\mathrm{ab}}$ & 1 \\
\hline
\end{tabular}

Note: Mean value followed by different letters a,b,c,d are significantly different at $\mathrm{p} \leq 0.05$.

As for the samples treated solely with LMwPF resin, $0,15 \%-0,29 \%$ weight loss was recorded, indicating very high resistance bestowed by the LMwPF treatment (Class 1). On the other hand, $0,10 \%-0,26 \%$ weight loss was observed after the addition of nano $\mathrm{ZnO}$ into LMwPF. From the results, the durability of $\mathrm{ZnO} /$ $\mathrm{H}_{2} \mathrm{O}$ treated rubberwood $(1,6 \%-15,0 \%)$ was significantly improved compared to that of the untreated samples $(26,7 \%)$. Although the improvements were relatively small when comparing with LMwPF and LMwPF/ZnO treatments, resistance Class 1 was achieved when the samples were submerged in the $\mathrm{ZnO} / \mathrm{H}_{2} \mathrm{O}$ solution for a long enough time before impregnation ( $\geq 90 \mathrm{~min}$ ).

On the other hand, LMwPF and LMwPF/ZnO treatments showed similar effectiveness against white-rot fungi. The physical barrier formed by the LmwPF and nano $\mathrm{ZnO}$ could prevent the wood from degraded by the digestive enzyme release by the fungus (Zanatta et al. 2017). In addition, reduction in the water absorption capacity of the wood as a result of decreased available void spaces is also a main factor that leads to the improvement in fungal resistance (Leemon et al. 2015). Suitable growing environment favored by the fungus was prevented as the water diffusivity in the wood was reduced (Nabil et al. 2016). Thus, the combination of both treatments resulted in the wood with very high resistance against fungal decay. The wood treated with LMwPF shows higher resistance to fungi because phenolic has a 3-dimensional network that is difficult to dissolve and degrade (Gusse et al. 2006). Clausen et al. (2010) also reported that the application of nano $\mathrm{ZnO}$ enhanced the resistance of wood against fungi and termites as well as protects the wood from UV degradation and prevents leaching. Improved decay resistance of particleboard treated with nano $\mathrm{ZnO}$ against Trametes versicolor and Coniophora puteana were reported by Marzbani et al. (2015). The author attributed the improvement to the antifungal properties of nano $\mathrm{ZnO}$.

The best time to submerge wood samples into all preservative treatment $\left(\mathrm{ZnO} / \mathrm{H}_{2} \mathrm{O}, \mathrm{LMwPF}, \mathrm{LMwPF} /\right.$ $\mathrm{ZnO}$ ) was $120 \mathrm{~min}$. The time of submersion into wood preservative affected the resistance of wood to fungi. Longer submersion period will improve the retention and therefore leads to higher resistance against fungi attack (Brelid et al. 2000). However, there was no significant difference between the submersion time for LM$\mathrm{wPF}$ and $\mathrm{LMwPF} / \mathrm{ZnO}$. Hence, the submersion time of $60 \mathrm{~min}$ for both treatments is sufficient while the nano $\mathrm{ZnO} / \mathrm{H}_{2} \mathrm{O}$ strictly requires submersion time of $120 \mathrm{~min}$ to attain significant improvement in decay resistance.

\section{CONCLUSIONS}

$\mathrm{ZnO}$ nanoparticles was successfully mixed with LMwPF and impregnated into rubberwood. The highest WPG was recorded from the rubberwood treated with $\mathrm{LMwPF} / \mathrm{ZnO}$ as the nanoparticles could facilitate the polymerisation and fixation of LMwPF resin immediately after impregnation. Well dispersion of the treatment solution and penetration into the rubberwood was observed as suggested by SEM image. Better thermal stability was observed in the treated rubberwood samples as lower mass loss was detected at the end of the TGA test, probably due to the higher WPG attained. As for decay resistance, the rubberwood treated with LMwPF and $\mathrm{LMwPF} / \mathrm{ZnO}$ possessed very high resistance against the white-rot fungus evaluated. The phenomenon might be attributed to the physical barrier formed by the LMwPF and nano $\mathrm{ZnO}$ that prevent the wood from 
degraded by the digestive enzyme release by the fungus. In addition, the hydrophobic characteristic of the wood after treatment also inhibits the growth of fungus that favour a high moisture environment. However, the rubberwood impregnated with $\mathrm{ZnO} / \mathrm{H}_{2} \mathrm{O}$ did not display similar effectiveness, except for the samples that were submerged in the treatment solution for 120 min before impregnation.

\section{ACKNOWLEDGMENTS}

The authors are grateful to the Forest Research Institute Malaysia (FRIM) and Higher Institution Centres of Excellence (HICoE) for providing the research materials and facilities.

\section{REFERENCES}

Akhtari, M.; Nicholas, D. 2013. Evaluation of particulate zinc and copper as wood preservatives for termite control. European Journal of Wood and Wood Products 71(3): 395-396.

American Society for Testing and Materials. ASTM. 2005. Standard Test method of accelerated laboratory test of natural decay resistance of woods. ASTM D2017-05. American Society for Testing and Materials: West Conshohocken, Pennsylvania.

Bahmani, M.; Schmidt, O. 2018. Plant essential oils for environment-friendly protection of wood objects against fungi. Maderas-Cienc Tecnol 20(3): 325-332.

Brelid, P.L.; Simonson, R.; Bergman, O.; Nilsson, T. 2000. Resistance of acetylated wood to biological degradation. Holz als Roh- und Werkstoff 58(5): 331-337.

Browne, F.G. 1961. The biology of Malayan Scolytidae and Platypodidae. Malayan Forest Record No. 22. Forest Department: Kuala Lumpur. (Accessed from) http://www.avocadosource.com/papers/Research_Articles/BrowneFG1961.pdf (consulted:1 October 2018).

Clausen, C.A.; Frederick, G.; Nami Kartal, S. 2010. Weatherability and leach resistance of wood impregnated with nano-zinc oxide. Nanoscale Research Letters 5(9): 1464-1467.

Dao, D.V.; Bremt, M.; Koeller, Z.; Le, T.K. 2016. Effect of metal ion doping on the optical properties and the deactivation of photocatalytic activity of $\mathrm{ZnO}$ nanopowder for application in sunscreens. Powder Technology 288(2016): 366-370.

Dhoke, S.K.; Khanna, A.S.; Sinha, T.J.M. 2009. Effect of nano-ZnO particles on the corrosion behavior of alkyd-based waterborne coatings. Progress in Organic Coatings 64(4): 371-382.

Dong, J.; Chen, L.; Liang, B.; Kong, J.; Zhao, H.; Liang, F. 2009. Research and application progress of water-soluble PF. China Adhesives 18(10): 37-41.

Dungani, D.; Islam, M.N.; Abdul Khalil, H.P.S.; Davoudpour, Y.; Rumidatul, A. 2014. Modification of the Inner Part of the oil palm trunk (OPT) with oil palm shell (OPS) nanoparticles and phenol formaldehyde (PF) resin: physical, mechanical, and thermal properties. BioResources 9(1): 455-471.

Fangli, Y.; Peng, H.; Chunlei, Y.; Shulan, H.; Jinlin, L. 2003. Preparation and properties of zinc oxide nanoparticles coated with zinc aluminate. Journal of Materials Chemistry 13(3): 634-637.

Furuno, T.; Imamura, Y.; Kajita, H. 2004. The modification of wood by treatment with low molecular weight phenol-formaldehyde resin: a properties enhancement with neutralized phenolic-resin and resin penetration into wood cell walls. Wood Science and Technology 37(5): 349-361. 
Gao, W.; Guo, C.; Yi, T.; Zhao, S.; Du, G. 2018. Dynamic mechanical thermal analysis (DMTA) of aqueous phenol formaldehyde (PF) resin modified by nano copper oxide (CuO). European Journal of Wood and Wood Products 76(4): 1145-1151.

Gallio, E.; Zanatta, P.; Riber, D.D.; Lazarotto M.; Gatto D.A.; Beltrame, R. 2018. Fourier Transform Infrared Spectroscopy in treated woods deteriorated by a white rot fungus. Maderas-Cienc Tecnol 20(3): 479488.

Ghorbani-Kookandeh, M.; Taghiyari, H.R.; Siahposh, H. 2014. Effects of heat treatment and impregnation with zinc-oxide nanoparticles on physical, mechanical, and biological properties of beech wood. Wood Science and Technology 48(4): 727-736.

Gusse, A.C.; Miller, P.D.; Volk, T.J. 2006. White-rot fungi demonstrate first biodegradation of phenolic resin. Environmental Science and Technology 40(13): 4196-4199.

Hong, L.T.; Tam, M.K.; Daljeet Singh K.; Omar, A. 1980. The Effectiveness of Preservatives in the Control of Sap-stain in Rubberwood (Hevea brasiliensis) Logs. Malaysian Forester 43(4): 522-527.

Huang, Y.; Fei, B.; Zhao, R. 2014. Investigation of low-molecular weight phenol formaldehyde distribution in Tracheid cell walls of Chinese Fir wood. Bioresources 9(3): 4150-4158.

Iždinský, J.; Reinprecht, L.; Nosál, E. 2018. Antibacterial efficiency of silver and zinc-oxide nanoparticles in acrylate coating for surface treatment of wooden composites. Wood Research 63(3): 365-372.

Jeon, S.K.; Kim, E.J.; Lee, J.; Lee, S. 2016. Potential risks of $\mathrm{TiO}_{2}$ and $\mathrm{ZnO}$ nanoparticles released from sunscreen into outdoor swimming pools. Journal of Hazardous Materials 317(2016): 312-318.

Jain, D.; Daima, H.K.; Kachhwaha, S.; Kothari, S.L. 2009. Synthesis of plant-mediated silver nanoparticles using papaya fruit extract and evaluation of their antimicrobial activities. Digest Journal of Nanomaterials and Biostructures 4(3): 557-563.

Lee, S.H.; Zaidon, A.; Lum, W.C.; Halip, J.A.; Ang, A.F.; Tan, L.P.; Chin, K.L.; Tahir, P.M. 2018. Thermal treatment of wood using vegetable oils: A review. Construction and Building Materials 181(2018): 408-419.

Lykidis, C.; Bak, M.; Mantanis, G.; Nemeth, R. 2016. Biological resistance of pine wood treated with nano-sized zinc oxide and zinc borate against brown-rot fungi. European Journal of Wood and Wood Products 74(6): 909-911.

Mantanis, G.; Terzi, E.; Kartal, S.N.; Papadoloulos, A.N. 2014. Evaluation of mold, decay and termite resistance of pine wood treated with zinc- and copper-based nanocompounds. International Biodeterioration \& Biodegradation 90(2014): 140-144.

Marzbani, P.; Mohammadnia Afrouzi, Y.; Omidvar A. 2015. The effect of nano-zinc oxide on particleboard decay resistance. Maderas-Cienc Tecnol 17(1): 63-68.

Nabil, F.L.; Zaidon, A.; Anwar, U.M.K.; Bakar, E.S.; Lee, S.H.; Paridah, M.T. 2016. Impregnation of sesenduk (Endospermum diadenum) wood with phenol formaldehyde and nanoclay admixture: effect on fungal decay and termites attack. Sains Malaysiana 45(2): 255-262.

Norhara, H. 1981. A Preliminary Assessment of the Relative Susceptibility of Rubberwood to Beetle Infestations. Malaysian Forester 44(4): 482-487.

Ratnasingam, J.; Ioras, F.; Wenming, L. 2011. Sustainability of the rubberwood sector in Malaysia. Notulae Botanicae Horti Agrobotanici Cluj-Napoca 39(2): 305-311.

Sawai, J. 2003. Quantitative evaluation of antibacterial activities of metallic oxide powders ( $\mathrm{nnO}, \mathrm{MgO}$ and $\mathrm{CaO}$ ) by conductimetric assay. Journal of Microbiological Methods 54(2): 177-182.

Sawai, J.; Yoshikawa, T. 2004. Quantitative evaluation of antifungal activities of metallic oxide powders ( $\mathrm{MgO}, \mathrm{CaO}$ and $\mathrm{ZnO}$ ) by conductimetric assay. Journal of Applied Microbiology 96(4): 803-809. 
Wang, X.; Lu, J.; Xu, M.; Xing, B. 2008. Sorption of pyrene by regular and nanoscaled metal oxide particles: influence of adsorbed organic matter. Environmental Science and Technology 42(19): 7267-7272.

Yang, I.; Kuo, M.; Myers, D.J. 2006. Soy protein combined with copper and boron compounds for providing effective wood preservation. Journal of the American Oil Chemists'Society 83(3): 239-239.

Zanatta, P.; Lzarotto, M.; Gonzalez De Cademartori P.H.; Da Silva Cava, S.; Moreira M. L.; Gatto, D.A. 2017. The effect of titanium dioxide nanoparticles obtained by microwave-assisted hydrothermal method on the color and decay resistance of pinewood. Maderas-Cienc Tecnol 19(4): 495-506.

Zuzanna, A.L.; William, W.Y.; Brittany, L.O.; Elizabeth, Q.C.; Vicki, L.C. 2013. Photochemical behaviour of nanoscale $\mathrm{TiO}_{2}$ and $\mathrm{ZnO}$ sunscreen ingredients. Journal of Photochemistry and Photobiology A: Chemistry 263(2013): 24-33. 